\title{
New Wave in Mobile Commerce Adoption via Mobile Applications in Malaysian Market: Investigating the Relationship Between Consumer Acceptance, Trust, and Self Efficacy
}

\author{
https://doi.org/10.3991/ijim.v12i7.8964 \\ Satwinderjit Singh, Izzal Asnira Zolkepli, Cheah Wen Kit( $\left(\varpi^{-}\right)$ \\ Universiti Sains Malaysia, Penang, Malaysia \\ cheah@inceptale.com
}

\begin{abstract}
Given the prevalence of online technology nowadays, mobile commerce continues to attract considerable attention for marketing research. However, studies on the factors that impact mobile commerce adoption via mobile applications are still limited. Moreover, there is minimal study that investigates the importance of attitudes towards mobile commerce as antecedents of mobile commerce adoption using Technology Acceptance Model (TAM), especially in the Malaysian market. These factors are crucial since the population of online users are massive and their influence is forming the untapped potential for marketers. By knowing the factors that drive the use of mobile commerce, this study seeks to facilitate marketers on how to use the findings and intensify the growth of online business in Malaysia. This quantitative study is crosssectional in nature with 160 samples. Results showed that out of six hypotheses, five hypotheses were supported. The findings shed lights on the relevance of TAM in reasoning the adoption of mobile commerce via mobile applications. Also, this study provides insightful implications for marketers to understand consumer behaviour and strengthen the mobile commerce market.
\end{abstract}

Keywords-Mobile Commerce, Mobile Applications, Technology Acceptance Model (TAM), Consumer Behaviour, Trust, Self-Efficacy.

\section{Introduction}

Understanding user's attitudes that drive online business is paramount to encourage present and future economic expansion, especially in emerging markets as it yields limitless growth opportunities. Goi [22] reported that mobile commerce market in Malaysia has earned MYR101 million in 2010 and MYR467 million in 2011 respectively. The explosive growth of $370 \%$ surpassed the growth of e-commerce which recorded only by $9 \%$ year-on-year increase. Sales transactions offer convenience as purchases can be made through mobile devices such as smartphones and handheld computers (also known as tablets) from anywhere in the world without time restrictions [7][44]. With the rapid proliferation of mobile devices, mobile commerce is 
widely recognised as the influential driving force for business practice. Kumar and Kumar [47] asserted that the increasing number of such connectivity hardware continue to transform various facets of global society. As the number of mobile device owners is predicted to reach ten billion globally by the year 2020 , the progressive features of mobile applications (apps) are contributing towards the democratisation in entrepreneurship. Mobile apps provide users with entertainment, social interactions, information, and further multi-functions via the internet [19][25]. Specifically, Zinnov [53] reported that $91 \%$ of mobile users are utilising apps to learn about particular product or service that they intend to purchase. Such finding opens up an opportunity for mobile apps developers to fully optimise the traffic to attract more users adopting mobile commerce [24][36]. Due to its convenience and availability, a higher number of Internet users would be capable in generating more businesses that witness the shift of consumerism through mobile commerce adoption [5][7][10][39].

Despite the growing interest from previous research, attitude towards mobile commerce in the context of mobile apps is also less explored. In addressing this, the present study aims to provide an empirical blueprint that investigates consumers' attitude as the antecedents of mobile commerce and mobile commerce adoption through a fundamental framework by adapting the Technology Acceptance Model (TAM). In addition, the study aims to investigate the role of perceived trust and perceived self-efficacy in influencing mobile commerce adoption. To the best of our knowledge, this study is among the earliest in studying the adoption of mobile commerce via mobile apps using the reasoning of TAM for the Malaysian market. Hence, its empirical finding would be beneficial to generalise the developing markets, especially with regards to the online user's attitude.

\section{Attitude towards Mobile Commerce}

In brief, the inception of mobile commerce was derived from the booming market of electronic commerce (e-commerce) that witnesses business activities performed through online services such as the world wide web and e-mail [15][39][50]. Ecommerce gives rise to the emergence of mobile commerce as the new wave of technology as these platforms are using the similar operating procedure [36]. These business activities are usually done through portable and non-wired connectivity devices using apps aimed at specific store activities such as product browsing and purchasing [41]. Previous literature asserted that mobile apps serve as a preliminary basis of mobile commerce in many ways. For instance, Carter and Yeo [9] regarded mobile apps users are the mobile commerce consumers as these users are prone to engage in online business while using their apps.

Consumers' mobile activity has motivated researchers to understand in detail their attitude towards apps usage so that they may offer marketing information and target personalised promotions to the potential customers [10][32]. However, such attempt would be a challenge when it comes to acquiring information about their behaviour regarding preferences, needs, and expectations for products and services in the market without fundamental understanding in mobile commerce [10]. Ketelaar et al. [29] 
argued that it is insufficient for marketers to rely on the existing knowledge of general marketing as consumers are more technology savvy and receptive to information across numerous online platforms. Hence, Wei et al. [49] found that the factors influencing consumers' decision to engage in mobile commerce are perceived usefulness, social influence, perceived cost, and trust are positively related to mobile commerce adoption. The finding has been echoed by Yadav et al. [51] who derived similar conclusion associated with the use of mobile commerce as well.

\section{Perceived Usefulness (PU)}

Roy and Moorthi [45] defined perceived usefulness as the extent to which an individual's expectations in using new technology will enhance his or her capability. It is a prominent component which is widely used in explaining consumer behaviour [46][51]. Kalinic and Marinkovic [28] reported that conversion rate of mobile commerce is at $50 \%$ for Japan, followed by the UK and South Korea with $40 \%$, while $32 \%$ in the United States. The sales are contributed by consumers' use of mobile devices and apps. As found by Kumar [30], mobile apps have generated about 20$30 \%$ of a retailer's mobile sales in the western markets due to its usefulness. The multi-functional mobile apps influenced a high number of consumers to visit the merchant's website, which contributes to higher sales, such as in the case of Amazon and Walmart [30]. The heightened growth of mobile commerce will continue to increase due to the growing demand from the consumers as the functionality of instant purchase with minimal procedures from browsing to payments that are appealing to the current millennial lifestyle. However, the intended optimisation of app may be hindered by complicated and complex usage. Hence, the following hypotheses are developed:

H1: Perceived Usefulness (PU) is positively related to the attitude towards mobile commerce.

\section{$4 \quad$ Perceived Ease-of-Use (PEoU)}

Davis [14] affirmed that even though consumers considered new technologies to be useful, they might also believe that the system could be a challenge to use due to its complexity. Wei et al. [49] argued that the complexity of the usage of the app will discourage the adoption of mobile commerce. Perceived ease-of-use may refer to the physical and mental effort. For instance, small and hard to read fonts, low-quality pictures, and difficulty to key in data are among reasons to hinder the mobile commerce adoption. Information overload, tedious steps in filling in personal details, and complicated configuration may force the consumers to be exhausted that result in losing interests to make online purchases. As such, developers and marketers are progressively strategising ways to offer seamless service experience to encourage long-term use of mobile commerce. Perceived ease-of-use in mobile commerce adoption reflects the degree to which an individual believes that using the same technology 
would require less effort [49]. It is found to be an essential factor to influence the consumer intention to use mobile commerce [5][46]. Hence, it is hypothesised that higher level of perceived ease of use may lead to higher probability of mobile commerce adoption.

H2: Perceived Ease of Use (PEoU) is positively related to the attitude towards mobile commerce

\section{$5 \quad$ Perceived Trust (PT)}

According to Ashraf et al. [5], the authors highlighted that a person's trust would influence his or her decision to adopt mobile commerce. The importance of users' trust is emphasised in the mobile commerce context as consumers are unable to touch, taste, or feel the product. Naqvi and Al-Shihi [40] asserted that trust plays a critical role in influencing users to engage in online business while encouraging them to reveal personal information. Previous literature have shown that trust leads to satisfactory transactions [27][28], reduces the process uncertainty [18][46], and enhances mobile commerce adoption [3][4]; provided that they possess the confidence towards its usage, which is denoted by the factor of self-efficacy. Therefore, it is hypothesised that:

H3: Perceived Trust (PT) is positively related to the attitude towards mobile commerce

\section{$6 \quad$ Perceived Self-Efficacy (PSE)}

Self-efficacy refers to an individual's belief or expectation on his or her ability, which is argued to influence behavioural change [6]. According to Ashraf et al. [5], perceived self-efficacy represents a person's belief or perceptions concerning own capacity to carry out a specific task using technology or mobile devices. It was argued that self-efficacy is able to predict of intentions and adoption [1][43], thus, validating one of the hypotheses of this study which is to link perceived self-efficacy and mobile commerce adoption.

Gitau and Nzuki [21] noted that high perceived self-efficacy enables an individual to perform the intended task in a mobile app more effectively, besides being more confident in exploring new technology. Consumers would feel more comfortable with the use of mobile commerce when perceived self-efficacy is embedded in their mind [37]. Alalwan et al. [4] confirmed that this factor has positively influenced consumers' intention to adopt telebanking through the studies on Jordanian consumers. In addition, Faqih and Jaradat [18] found that perceived self-efficacy is significantly related to the adoption of mobile commerce.

As noted by Islam et al. [26], perceived self-efficacy is as equally crucial as trust factor for mobile commerce since both traits represent psychological factors of online users. They asserted that individuals with high perceived self-efficacy are prone to 
adopt mobile commerce more effectively as they expect the system to be userfriendly, easy to use, and more likely to use mobile commerce continuously. Even though some there were studies that revealed the effects of trust on user behaviour [5][27][33], there is still a lack of research on the role of perceived self-efficacy towards mobile commerce via mobile apps, specifically. Along with perceived ease-ofuse, perceived usefulness, and trust, perceived self-efficacy factor is proposed to be included in the existing Technology Acceptance Model (TAM), which forms the theoretical basis for the present study. Therefore, it is hypothesised that:

H5: Perceived Self-Efficacy (PSE) is positively related to the mobile commerce adoption

\section{Technology Acceptance Model}

Based on Technology Acceptance Model (TAM), the intention to use a type of technology is determined by an individual's attitude, which are perceived usefulness, perceived ease-of-use, perceived trust and perceived self-efficacy in the present context. Extant studies have empirically validated the applicability of TAM in various research fields, such as for education [2][38], online shopping [5][20], social media [17], and tourism [13][35], amongst others. Nevertheless, prior studies were primarily focused on the main constructs of TAM namely; perceived usefulness and perceived ease-of-use with less attention paid to the dimensions of trust and self-efficacy.

Under the fundamentals of TAM, a person's behavioural intention is a direct function of attitude towards technology usage [5]. The researchers have also argued that perceived usefulness and perceived ease-of-use employed mutually to establish an individual's attitude towards the use of a technology [5], namely mobile commerce. Consumers' expectations in adopting mobile commerce are based on the ease transaction process and how the transactions satisfy their needs, which relates to their perceived usefulness. Goi [22] highlighted that TAM components offer a balanced and appropriate view to evaluate the consumers' drive in using mobile commerce since perceived ease-of-use is regarded as intrinsic motivation whereas perceived usefulness provides extrinsic motivation.

By fulfilling these two needs, consumers are ready to conduct online purchases and accept the idea of mobile commerce. However, some researchers have failed to link perceived ease-of-use with mobile commerce adoption by comparing perceived usefulness and perceived ease of use [51], which influenced other researchers to ignore this variable [4][31]. Motivated by this, the present study tests both components in influencing mobile commerce adoption rather than focusing on a single component based on the original TAM model, regardless of the insignificant findings from previous studies. Hence, the extended TAM with the additional construct of trust developed by Dahlberg et al. [12] appears more suitable to be used as an underlying theory in explaining consumer's behavioural intention to adopt mobile commerce compared the original attributes of TAM. Such approach is supported and widely discussed in the past literature [5][20][46][49]. 
In relation to user's attitude concerning TAM components, perceived usefulness, perceived ease-of-use and perceived trust were consistently found to be significant in improving mobile commerce adoption. Based on the theoretical background, the research framework presented six hypotheses with six constructs namely; perceived usefulness, perceived ease of use, perceived trust, perceived self-efficacy, attitude towards mobile commerce, and mobile commerce adoption. Hence, the following hypotheses are developed:

H4: Perceived Usefulness (PU) is positively related to the mobile commerce adoption

H6: Attitude towards mobile commerce is positively related to the mobile commerce adoption

Figure 1 shows the research framework for the present study. It has in total 6 hypotheses as explained earlier.

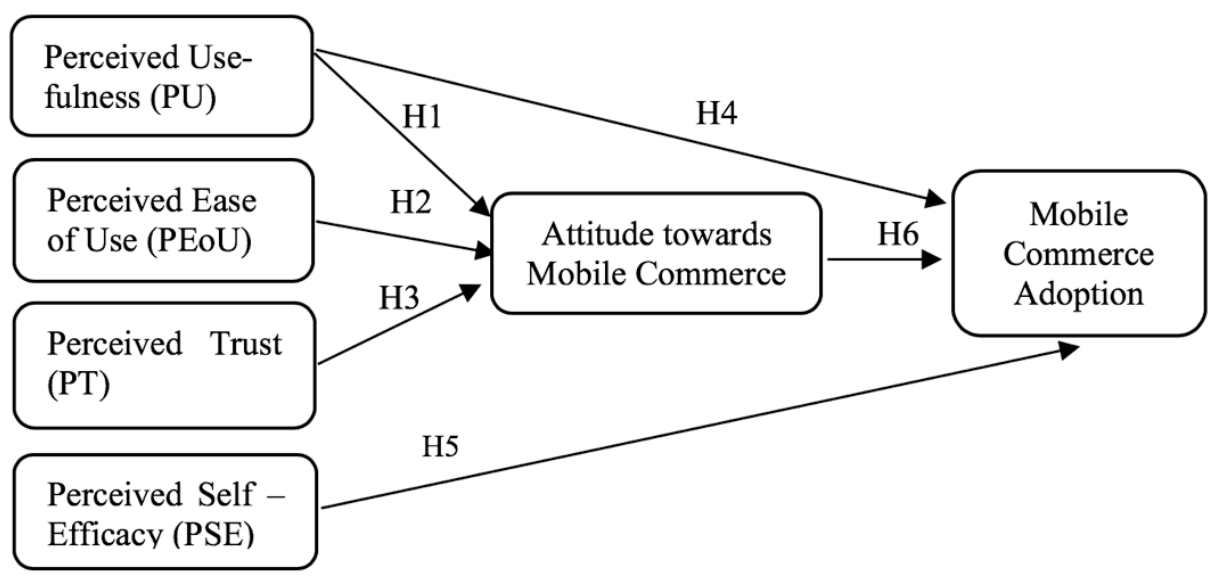

Fig. 1. Research Framework

\section{$8 \quad$ Methods}

Based on the objective, targeted samples were aimed to represent diverse age groups, ethnicity, and level of income that yields the highest likelihood to adopt mobile commerce in Malaysia. Due to its highest number of users, Facebook is selected as the platform to disseminate the link of the online survey [16]. This study used convenience sampling to select respondents among Facebook users in Malaysia. The online survey was conducted in April 2016 while 160 usable questionnaires were collected. All data were coded in Statistical Package for Social Science (SPSS) version 22.0. With regards to the preliminary analysis, data cleaning and data transformation were performed to identify any missing value, outliers. The reverse items used 
in the questionnaire were also re-coded. The questionnaires consist of 30 items using 7-point Likert scale (ranging from $1=$ strongly disagree to $7=$ strongly agree.).

\section{$9 \quad$ Samples}

The sample was primarily comprised of females (53.1\%) and aged ranging from 25 to 34 years old $(50 \%)$. Almost half of the sample uses mobile commerce at least once a month (48.8\%). Table 1 provides the demographic profile of the sample. Before the actual data collection, a pilot test was conducted among 50 Master's Degree students in Universiti Sains Malaysia Kuala Lumpur (USMKL). Some items were revised according to the feedback from the pilot test. The items were proofread for spelling, grammar, and flow of the questionnaire as well. Overall, the questionnaire is deemed as objective, direct, and easy to understand.

Table 1. Demographic profile

\begin{tabular}{|l|l|l|l|l|l|l|l|}
\hline Gender & $(\mathbf{\% )}$ & Education & $\mathbf{( \% )}$ & Level of income & $\mathbf{( \% )}$ & Usage reason & $\mathbf{( \% )}$ \\
\hline Female & 53.1 & $\begin{array}{l}\text { Secondary } \\
\text { school }\end{array}$ & 10.1 & Below RM500 & 23.1 & For personal & 88.1 \\
\hline Male & 46.9 & Degree & 58.8 & RM501-RM2000 & 13.1 & For work & 6.3 \\
\hline & & Masters & 21.9 & RM2001-RM4000 & 23.2 & For school & 5.6 \\
\hline & & PhD & 9.2 & RM4001 and more & 40.6 & & \\
\hline
\end{tabular}

Note: $*$ Usage $=$ Mobile Commerce Usage

\subsection{Measures}

This study consists of five independent variables and one dependent variable. In particular, five questions were asked for each variable that made-up a total of 30 items in the overall questionnaire. To measure the dependent variable, the respondents rated their intention to use mobile commerce based on statements such as: (1) I have the necessary resources to use mobile commerce, and (2) I am interested to use mobile commerce from my mobile apps. Selected statements on other variables were provided as follows: (1) Mobile commerce services are useful to me as a consumer (Perceived Usefulness), (2) I find it easy to use mobile commerce services (Perceived

Ease-of-Use), (3) I am confident to use mobile commerce (Perceived SelfEfficacy), (4) I believe that mobile commerce is reliable (Perceived Trust), and (5) The use of mobile commerce provides pleasure to me (Attitude towards using mobile commerce).

Items on perceived usefulness, perceived ease-of-use, and attitude towards the use of mobile commerce were adapted from Davis [14]. Items on perceived trust were adapted from Gefen et al. [20], whereas perceived self-efficacy was measured using items developed by Compeau and Higgins [11]. 


\subsection{Results}

To test the hypotheses on the relationships among all constructs, the present study analysed correlation and regression analysis. Correlation analysis explains the relationship between the independent and dependent variables whereas regression analysis justifies the impact of independent variables on dependent variable [23]. Prior to conducting the main analysis, construct reliability for all variables were examined (Table 2). The measurement items were included under each variable in the table below. The results of Cronbach's Alpha were exceeding $0.90(\alpha>0.90)$, representing high internal consistency among the items [42].

To measure construct validity, factor analysis was performed using a principal component for analysis associated with varimax rotation. Kaiser Meyer-Olkin (KMO) measure of sampling adequacy was 0.936 indicating sufficient inter-correlations while Bartlett's Test of Sphericity was significant ( $p>0.05)$. Results of correlation analysis showed positive and significant at 0.001 levels (2-tailed), which concluded that discriminant validity had been established.

To test the hypotheses, multiple regressions were carried out to examine the impact of independent variables on the dependent variable. Since this study is interested in investigating the antecedents of attitude towards mobile commerce as well as mobile commerce adoption, thus, there are two coefficients of determination should be reported. Table 4 shows the results of hypotheses-testing.

Table 4 reports that all of the hypotheses were supported except for $\mathrm{H} 4$ (perceived usefulness $\rightarrow$ mobile commerce adoption). In particular, the positive effects of perceived usefulness and perceived ease-of-use on attitude were both significant and strong $(\beta=0.461, t=8.421, p<0.00 ; \beta=0.334, t=6.207, p<0.00)$, which supported H1 and $\mathrm{H} 2$. Perceived trust showed a positive and significant effect on attitude towards mobile commerce, thus, supported H3. The significant change in $\mathrm{R}$-square $\left(\mathrm{R}^{2}=0.644\right)$ indicated that $64.4 \%$ of the variance in attitude towards mobile commerce could be explained by perceived usefulness, perceived ease-of-use, and perceived trust.

Similarly, perceived self-efficacy and attitude towards mobile commerce have a significant impact on mobile commerce adoption; thus, confirmed H5, and H6. However, the relationship between perceived usefulness and mobile commerce adoption was found to be insignificant. Overall, the significant change in $R$-square $\left(R^{2}=0.612\right)$ indicated that attitude and perceived self-efficacy is able to explain $61.2 \%$ of the variance in mobile commerce adoption. 
Table 2. Constructs Reliability

\begin{tabular}{|c|c|c|c|c|c|}
\hline Constructs & Items & Measurement Items & Mean & SD & $\begin{array}{c}\text { Cronbach's } \\
\text { Alpha }\end{array}$ \\
\hline \multirow[t]{6}{*}{ Perceived Usefulness } & & & 3.6438 & 0.95105 & 0.942 \\
\hline & PU1 & \multicolumn{4}{|c|}{ Using mobile commerce services makes me save time. } \\
\hline & PU2 & \multicolumn{4}{|c|}{ Mobile commerce services make me a better consumer. } \\
\hline & PU3 & \multicolumn{4}{|c|}{ Using mobile commerce services improves my efficiency as a consumer. } \\
\hline & PU4 & \multicolumn{4}{|c|}{ Mobile commerce services are useful to me as a consumer. } \\
\hline & PU5 & \multicolumn{4}{|c|}{ Mobile commerce services increase my effectiveness as a consumer. } \\
\hline \multirow[t]{6}{*}{ Perceived Ease-of-Use } & & & 3.6012 & 1.00352 & 0.965 \\
\hline & PEoU1 & \multicolumn{4}{|c|}{ Learning to use mobile commerce services is easy to me. } \\
\hline & PEoU2 & \multicolumn{4}{|c|}{ It is easy to make mobile commerce services do what I want them to. } \\
\hline & PEoU3 & \multicolumn{4}{|c|}{$\begin{array}{l}\text { My interaction with mobile commerce services is clear and understand- } \\
\text { able. }\end{array}$} \\
\hline & PEoU4 & \multicolumn{4}{|c|}{ I find it easy to interact with mobile commerce services. } \\
\hline & PEoU5 & \multicolumn{4}{|c|}{ I find it easy to use mobile commerce services. } \\
\hline \multirow[t]{6}{*}{ Perceived Self Efficacy } & & & 3.7312 & 0.96948 & 0.945 \\
\hline & PSE1 & \multicolumn{4}{|c|}{ I am able to use mobile commerce services without the help of others. } \\
\hline & PSE2 & \multicolumn{4}{|c|}{$\begin{array}{l}\text { I have the necessary time to make mobile commerce services useful to } \\
\text { me. }\end{array}$} \\
\hline & PSE3 & \multicolumn{4}{|c|}{$\begin{array}{l}\text { I have the knowledge and skills required to use mobile commerce ser- } \\
\text { vices. }\end{array}$} \\
\hline & PSE4 & \multicolumn{4}{|c|}{ I am able to use mobile commerce services reasonably well on my own. } \\
\hline & PSE5 & \multicolumn{4}{|c|}{$\begin{array}{l}\text { I have started using mobile commerce after witnessing and hearing the } \\
\text { feedback from people around me. }\end{array}$} \\
\hline \multirow[t]{6}{*}{ Perceived Trust } & & & 3.3325 & 0.98719 & 0.912 \\
\hline & PT1 & \multicolumn{4}{|c|}{ In my opinion, $\mathrm{m}$-commerce is very reliable } \\
\hline & PT2 & \multicolumn{4}{|c|}{ I believe in the information that $\mathrm{m}$ - commerce provides } \\
\hline & PT3 & \multicolumn{4}{|c|}{ I can rely on Mobile Commerce to execute my transactions reliably } \\
\hline & PT4 & \multicolumn{4}{|c|}{$\begin{array}{l}\text { Given the state of existing m-commerce, I believe that technology related } \\
\text { error is rare. }\end{array}$} \\
\hline & PT5 & \multicolumn{4}{|c|}{ I trust my mobile service providers when using mobile application. } \\
\hline \multirow[t]{6}{*}{ Attitude } & & & 3.5313 & 0.99812 & 0.956 \\
\hline & ATT1 & \multicolumn{4}{|c|}{ I like to use Mobile Commerce. } \\
\hline & \begin{tabular}{|l|} 
ATT2 \\
\end{tabular} & \multicolumn{4}{|c|}{ It is pleasure for me to use Mobile Commerce. } \\
\hline & ATT3 & \multicolumn{4}{|c|}{ It is desirable for me to learn how to use Mobile Commerce. } \\
\hline & ATT4 & I can shop and search for & ed produ & easily. & \\
\hline & ATT5 & I am satisfied with purcha & ow transe & $n$ in a mob & application. \\
\hline Adoption & & & 3.5313 & 0.99812 & 0.951 \\
\hline & ADP1 & I intend to use the mobile & ication th & gh a device & the future. \\
\hline & ADP2 & I predict that I would use & nobile sit & rough a de & e in future. \\
\hline & ADP3 & I have the necessary mean & d resourc & o use mobil & ommerce. \\
\hline & ADP4 & $\begin{array}{l}\text { I would like to try new wa } \\
\text { mobile commerce. }\end{array}$ & $\mathrm{f}$ doing $\mathrm{t}$ & s such as $\mathrm{p}$ & hasing through \\
\hline
\end{tabular}

Note: $\mathrm{SD}=$ Standard Deviations; PU=Perceived Usefulness; PEoU=Perceived Ease of Use; PSE=Perceived Self-Efficacy; PT=Perceived Trust; ATT=Attitude towards the use of mobile commerce; Adoption=Mobile commerce adoption. 
Table 3. Results of Correlation Analysis

\begin{tabular}{|l|c|c|c|c|c|c|}
\hline & $\mathbf{1}$ & $\mathbf{2}$ & $\mathbf{3}$ & $\mathbf{4}$ & $\mathbf{5}$ & $\mathbf{6}$ \\
\hline Perceived Ease of Use & 1 & & & & & \\
\hline Perceive Usefulness & $.703^{* *}$ & 1 & & & & \\
\hline $\begin{array}{l}\text { Attitude Towards Mobile Com- } \\
\text { merce }\end{array}$ & $.788^{* *}$ & $.830^{* *}$ & 1 & & & \\
\hline Mobile Commerce Adoption & $.788^{* *}$ & $.830^{* *}$ & $1.000^{* *}$ & 1 & & \\
\hline Perceived Self Efficacy & $.751^{* *}$ & $.808^{* *}$ & $.839^{* *}$ & $.839^{* *}$ & 1 & \\
\hline Perceived Trust & $.626^{* *}$ & $.644^{* *}$ & $.715^{* *}$ & $.715^{* *}$ & $.629^{* *}$ & 1 \\
\hline
\end{tabular}

$* \mathrm{p}<0.05, * * \mathrm{p}<0.01$

Table 4. Results of hypotheses-testing

\begin{tabular}{|l|l|l|l|l|}
\hline \multicolumn{1}{|c|}{ Hypothesis } & \multicolumn{1}{c|}{$\boldsymbol{\beta}$} & \multicolumn{1}{c|}{ T-value (t) } & \multicolumn{1}{c|}{ P-value (Sig) } & \multicolumn{1}{c|}{ Results } \\
\hline $\mathrm{H} 1: \mathrm{PU} \rightarrow$ ATT & 0.461 & 8.421 & $0.000^{* *}$ & Supported \\
\hline $\mathrm{H} 2: \mathrm{PEOU} \rightarrow$ ATT & 0.334 & 6.207 & $0.000^{* *}$ & Supported \\
\hline $\mathrm{H} 3: \mathrm{PT} \rightarrow$ ATT & 0.209 & 4.188 & $0.000^{* *}$ & Supported \\
\hline H4: $\mathrm{PU} \rightarrow$ Adoption & -0.050 & -0.718 & 0.474 & Not Supported \\
\hline H5: PSE $\rightarrow$ Adoption & 0.377 & 5.909 & $0.000^{* *}$ & Supported \\
\hline H6: ATT $\rightarrow$ Adoption & 0.538 & 9.861 & $0.000^{* *}$ & Supported \\
\hline
\end{tabular}

Note: $* \mathrm{p}<0.05, * * \mathrm{p}<0.01$

$\mathrm{PU}=$ Perceived Usefulness; PEoU=Perceived Ease of Use; PT=Perceived Trust; PSE=Perceived SelfEfficacy; ATT=Attitude towards mobile commerce; Adoption=Mobile commerce adoption

\section{Discussion}

The primary intent of this study was to shed light on the factors that influence attitude towards mobile commerce and predict which factors related to mobile commerce adoption. There are initial three objectives that were expected to achieve in the present research. First, the applicability of TAM as the underlying theory in explaining mobile commerce adoption. Even though this theory has been consistently applied in the previous studies [4][17][18][35], the absence of attitude towards the intention to use new technology such as mobile commerce shows a gap of knowledge.

Although the main idea was to identify the factors influencing mobile commerce adoption, the attitude towards mobile commerce is integral to be highlighted since it is an antecedent of the adoption factor. As noted by Ashraf et al. [5], attitude is a strong and direct mechanism to predict usage. Indeed, this study revealed that attitude has the strongest coefficient towards mobile commerce adoption, followed by perceived usefulness, perceived self-efficacy, perceived ease-of-use, and perceived trust. Therefore, the present study strengthens the use of TAM to be applied in future marketing research by taking into account the fundamental factors of the model with additional components of perceived self-efficacy and trust.

The role of perceived trust in affecting attitude towards mobile commerce was examined as well. The results showed that perceived trust has significantly influenced 
the attitude towards mobile commerce. This result supported the claims by Alalwan et al. [4] and Ashraf et al. [5] on the importance of trust in moulding consumer's attitude towards mobile commerce. The authors also argued that perceived trust is crucial especially when there is no physical contact or face-to-face communication between consumers and mobile commerce retailers. Further, the consumers are most likely to rely on perceived trust to lessen their concerns and thereafter approved their decisions to adopt mobile commerce.

The third objective is to explore the role of perceived self-efficacy as antecedent of mobile commerce adoption since it was discussed in past literature. Researchers affirmed that self-efficacy impactfully plays such an imperative role in predicting consumers' perception and their intentions to adopt new technology such as mobile commerce [4][54]. Even though the journey towards systematic implementation of mobile commerce in Malaysia seems to be far ahead, high self-efficacy among consumers enables them to adopt mobile commerce continuously. Such understanding is supported by the original definition of self-efficacy by Bandura [6] that portrays individuals' judgments on their capabilities to act accordingly in order to achieve their performance and goals. In this context, the consumers' personal confidence is influencing their actions to accept and enhance the possibility to successfully adopt mobile commerce.

The findings in this paper contribute to the literature in two important ways. First, this paper addresses the call for more research on individual-level variables as determinants of mobile commerce adoption. There is a paucity of research on consumer behaviour based on TAM in emerging market, such as Malaysia. The understanding of mobile commerce adoption is crucial in this context especially that the penetration of technology advancement and internet connectivity is at its pinnacle. The multifunctional features of mobile apps are capable of influencing the consumers' perceptions to engage in mobile commerce [48]. For instance, location-based apps allow marketers to access the consumers' specific region or area to distribute location-based coupons, promotions, discounts, or other relevant information [8]. This research provides valuable insights and fundamental blueprint for mobile commerce retailers as well as apps developers on what to expect and how to attract mobile users to engage in mobile commerce.

Theoretically, this study shows that the components of TAM are relevant in today's marketing research, with certain exceptions. For instance, previous studies provide evidence that perceived usefulness is significantly related to behavioural intention [2][18] but this study presents contrary findings. The plausible reason is related to the point of view of the current sample, which is denoted by their age group, level of education and criticality in decision-making. Millennial consumers are no longer looking at the main functions of a product before conducting an online transaction, but they are more interested in looking at other features such as the current trend, promotional price, gifts, and reviews from other consumers [29][34][52]. Thus, it can be concluded that other intervening factors are also influencing the adoption of mobile commerce other than perceived usefulness.

Furthermore, this study also strengthens the ongoing debate with regards to perceived trust and perceived self-efficacy in influencing mobile commerce adoption. 
Notwithstanding the existing studies on this topic, their findings showed mixed results. Further, by taking into consideration the different cultures, economic growth, and technology penetration, the generalisation of previous studies were questioned. Hence, this study provides insights on how Asian consumers in emerging economy from diverse background regardless of gender, age groups, ethnicity, and level of income showed interest to adopt mobile commerce based on perceived self-efficacy and trust. Indirectly, since Malaysia is a multi-ethnicity country, samples in this study is capable of representing a portion of the Asian market.

\section{Limitations and Future Research}

This study has its limitations that suggest opportunities for future research. The first concern would be a limited number of respondents. The inclusion of filter questions such as whether the respondents understand mobile commerce or if they had experience dealing with it had limited the possible samples. In future, researchers are advised to include examples of mobile commerce, such as mobile ticketing, mobile banking, information services, and mobile payment while providing the trade name of the highly-used apps that implement mobile commerce.

In addition, the data collection platform could be improved by distributing the questionnaires' link via various social media platforms such as Instagram, Twitter, and WeChat. Furthermore, a longer duration to collect the data is suggested to increase the response rate. In this regard, future research could compare any data variation based on social media platforms as well as to examine any difference if data was collected at the beginning or at the end of the month.

Another limitation relates to the research framework and data analysis. This study proposed that there are three factors that influence attitude towards mobile commerce in addition to three factors that would influence mobile commerce adoption. Therefore, future research might employ Structural Equation Modelling (SEM) to test all the relationships at once and examine the possible role of attitude towards mobile commerce as a mediator using the Bootstrapping procedure. Hence, a more comprehensive framework with a different analysis structure would enrich the available knowledge while contributing to the current gap of marketing research.

\section{Conclusion}

Despite these limitations, all factors showed positive and significant relationships towards mobile commerce adoption except for perceived usefulness, which the plausibility described earlier. This study confirmed that perceived usefulness is significant to attitude towards mobile commerce but unable to show the relationship between mobile commerce adoption. This finding revealed that consumers would consider other factors rather than perceived usefulness before engaging in mobile commerce. The present study also provides evidence on the association of attitude towards mobile commerce as a necessary antecedent of mobile commerce adoption based on the data analysis of its strongest beta coefficient. As such, it is strongly suggested for 
future digital marketing research to consider this approach since the direct relationship between factors leading to mobile commerce adoption might produce statistically low significance.

The present study has expanded the current understanding of mobile commerce adoption through the fundamental constructs of TAM, which are attitudes towards mobile commerce, perceived trust, and perceived self-efficacy. Through the proposed research framework, this study recognised the essential construct of perceived trust and perceived self-efficacy in predicting mobile commerce adoption in the existing TAM.

\section{Acknowledgement}

This research is fully funded by Universiti Sains Malaysia under the Short-term Grant number 304/PCOMM/6313213.

\section{References}

[1] Ajzen, I, "The Theory of Planned Behavior". Organizational Behavior and Human Decision Processes, vol. 50, no. 2, pp. 179-211, 1991.

[2] Al-Azawei, A., Parslow, P., \& Lundqvist, K, Investigating the effect of learning styles in a blended e-learning system: An extension of the technology acceptance model (TAM). Australasian Journal of Educational Technology, vol. 33, no. 2, pp. 1-23, 2017.

[3] Alqatan, S., Noor, N. M. M., Man, M., \& Mohemad, R, An empirical study on success factors to enhance customer trust for mobile commerce in small and medium-sized tourism enterprises (SMTES) in Jordan. Journal of Theoretical and Applied Information Technology, vol. 83, no. 3, pp. 373-398, 2016.

[4] Alalwan, A. A., Dwivedi, Y. K., Rana, N. P., \& Simintiras, A. C. Jordanian consumers' adoption of telebanking: Influence of perceived usefulness, trust and selfefficacy, International Journal of Bank Marketing, vol. 34, no. 5, pp. 690-709, 2016.

[5] Ashraf, A. R., Thongpapanl, N., \& Auh, S., The application of the technology acceptance model under different cultural contexts: The case of online shopping adoption. Journal of International Marketing, vol. 22, no. 3, pp. 68-93, 2014. https://doi.org/10.1108/IJBM-062015-0093

[6] Bandura. A., Social foundations of thought and action: A social cognitive theory. Englewood Cliffs, NJ: Prentice Hall, 1986.

[7] Barua, B. M-Commerce in Bangladesh-Status, Potential and Constraints. International Journal of Information Engineering and Electronic Business, vol. 8 no. 6, pp. 22-27, 2016. https://doi.org/10.5815/ijieeb.2016.06.03.

[8] Bhave, K., Jain, V., \& Roy, S., Understanding the orientation of Gen Y toward mobile applications and in-app advertising in India. International Journal of Mobile Marketing, vol. 8, no. 1, pp. 62-74, 2013.

[9] Carter, S., \& Yeo, A. C. M. Mobile apps usage by Malaysian business undergraduates and postgraduates: Implications for consumer behaviour theory and marketing practice. Internet Research, vol. 26, no. 3, pp. 733-757, 2016. https://doi.org/10.1108/IntR-102014-0273. 
[10] Chen, Q., Zhang, M., \& Zhao, X. Analysing customer behaviour in mobile app usage. Industrial Management \& Data Systems, vol. 117, no. 2, pp. 425 438, 2017. https://doi.org/10.1108/IMDS-04-2016-0141.

[11] Compeau, D. R., \& Higgins, C. A. Application of social cognitive theory to training for computer skills. Information Systems Research,6(2), pp. 118-143, 1995. https://doi.org/10.1287/isre.6.2.118.

[12] Dahlberg, T., Mallat, N., \& Oorni, A. Trust enhanced technology acceptance model consumer acceptance of mobile payment solutions: Tentative evidence. Stockholm Mobility Roundtable, vol. 22, pp. 23-33, 2003.

[13] Dajani, D. Using the Unified Theory of Acceptance and Use of Technology to Explain Ecommerce Acceptance by Jordanian Travel Agencies. Journal of Comparative International Management, vol. 19, no. 1, pp. 121-144, 2016.

[14] Davis, F. D. Perceived usefulness, perceived ease of use, and user acceptance of information technology. MIS Quarterly, vol. 13, no. 3, pp. 319-340, 1989. https://doi.org/10.2307/249008.

[15] Ding, Y., \& Chai, K. H. Emotions and continued usage of mobile applications. Industrial Management \& Data Systems, vol. 115 no. 5, pp. 833-852, 2015. https://doi.org/10.1108/ IMDS-11-2014-0338.

[16] Duffett, R. G. Facebook advertising's influence on intention-to-purchase and purchase amongst Millennials. Internet Research, vol. 25, no. 4, pp. 498-526, 2015. https://doi.org/10.1108/IntR-01-2014-0020.

[17] Dumpit, D. Z., \& Fernandez, C. J. Analysis of the use of social media in Higher Education Institutions (HEIs) using the Technology Acceptance Model. International Journal of Educational Technology in Higher Education, 14(1), pp. 1-16, 2017. https://doi.org/10.1186/ s41239-017-0045-2.

[18] Faqih, K. M., \& Jaradat, M. I. R. M. Assessing the moderating effect of gender differences and individualism-collectivism at individual-level on the adoption of mobile commerce technology: TAM3 perspective. Journal of Retailing and Consumer Services, vol. 22, pp. 37-52, 2015. https://doi.org/10.1016/j.jretconser.2014.09.006.

[19] Finkelstein, A., Harman, M., Jia, Y., Martin, W., Sarro, F., \& Zhang, Y. Investigating the relationship between price, rating, and popularity in the Blackberry World App Store. Information and Software Technology, vol. 87, pp. 119-139, 2017. https://doi.org/10.1016/j.infsof.2017.03.002.

[20] Gefen, D., Karahanna, E., \& Straub, D. W. Trust and TAM in online shopping: An integrated model. MIS Quarterly, vol. 27, no. 1, 51-90, 2003.

[21] Gitau, L., \& Nzuki, D. Analysis of determinants of m-commerce adoption by online consumers. International Journal of Business, Humanities and Technology, vol. 4, no. 3, pp. 88-94, 2014.

[22] Goi, C. L. M-Commerce: Perception of Consumers in Malaysia. The Journal of Internet Banking and Commerce, 2016. [Online]. Available: http://www.icommercecentral.com/ open-accemcommerce-perception-of-consumers-in-malaysia.php?aid=80469.

[23] Griffith, A. SPSS. Hoboken, NJ: Wiley Publishing, 2010.

[24] Hernandez-Ortega, B., Aldas-Manzano, J., Ruiz-Mafe, C., \& Sanz-Blas, S., Perceived value of advanced mobile messaging services: A cross-cultural comparison of Greek and Spanish users. Information Technology \& People, vol. 30, no. 2, 324-355, 2017. https://doi.org/10.1108/ITP-01-2014-0017.

[25] Hsiao, C. H., Chang, J. J., \& Tang, K. Y. (2016). Exploring the influential factors in continuance usage of mobile social Apps: Satisfaction, habit, and customer value perspec- 
Paper-New Wave in Mobile Commerce Adoption via Mobile Applications in Malaysian Market: Inv...

tives. Telematics and Informatics, vol. 33, no. 2, pp. 342-355, 2016. https://doi.org/10.1016/j.tele.2015.08.014.

[26] Islam, M. A., Khan, M. A., Ramayah, T., \& Hossain, M. M. The adoption of mobile commerce service among employed mobile phone users in Bangladesh: self-efficacy as a moderator. International Business Research, vol. 4, no. 2, pp. 80-89, 2011.

[27] Joubert, J., \& Van Belle, J. The role of trust and risk in mobile commerce adoption within South Africa. International Journal of Business, Humanities and Technology, vol. 3, no. 2, pp. 27-38, 2013.

[28] Kalinic, Z., \& Marinkovic, V. Determinants of users' intention to adopt m-commerce: an empirical analysis. Information Systems and e-Business Management, vol. 14(2), pp. 367387, 2016. https://doi.org/10.1007/s10257-015-0287-2.

[29] Ketelaar, P. E., Willemsen, L. M., Sleven, L., \& Kerkhof, P. The good, the bad, and the expert: How consumer expertise affects review valence effects on purchase intentions in online product reviews. Journal of Computer-Mediated Communication, vol. 20, no. 6, 649-666, 2015. https://doi.org/10.1111/jcc4.12139.

[30] Kumar, H. Mobile Commerce Trends to Buy Into. Marketing Insights, pp. 20-21, 2016.

[31] Lee, H. M., \& Chen, T. Perceived quality as a key antecedent in continuance intention on mobile commerce. International Journal of Electronic Commerce Studies, vol. 5, no. 2, pp. 123-142, 2014. https://doi.org/10.7903/ijecs.1150.

[32] Leonardi, P. M., Huysman, M., \& Steinfield, C. Enterprise social media: Definition, history, and prospects for the study of social technologies in organizations. Journal of Computer-Mediated Communication, vol. 19, no. 1, pp. 1-19, 2013. https://doi.org/10.1111/ jec4.12029.

[33] Li, Y. M., \& Yeh, Y. S. Increasing trust in mobile commerce through design aesthetics. Computers in Human Behavior, vol. 26, no. 4, pp. 673-684, 2010. https://doi.org/10.1016/j.chb.2010.01.004.

[34] Lim, Y. S., \& Van Der Heide, B. Evaluating the wisdom of strangers: The perceived credibility of online consumer reviews on Yelp. Journal of Computer-Mediated Communication, vol. 20, no. 1, pp. 67-82, 2015. https://doi.org/10.1111/jec4.12093.

[35] Lin, H. F., \& Chen, C. H. Combining the Technology Acceptance Model and Uses and Gratifications Theory to examine the usage behavior of an Augmented Reality Toursharing Application. Symmetry, 9(113), pp. 1-22, 2017. https://doi.org/10.3390/sym907 $\underline{0113}$.

[36] Lu, Y., \& Rastrick, K. Impacts of website design on the adoption intention of mobile commerce: Gender as a moderator. New Zealand Journal of Applied Business Research, vol. 12, no. 2, pp. 51-68, 2014.

[37] Marriott, H. R., Williams, M. D., \& Dwivedi, Y. What do we know about consumer mshopping behaviour? International Journal of Retail \& Distribution Management, vol. 45, no. 6, pp. 568-586, 2017. https://doi.org/10.1108/IJRDM-09-2016-0164.

[38] Masood, A., \& Lodhi, R. N. Determinants of behavioral intentions to use SPSS among students: Application of Technology Acceptance model (TAM). FWU Journal of Social Sciences, vol. 10, no. 2, pp. 146-152, 2016.

[39] Moorthy, K., S.L. Ching, Fatt, Y. W., Yee, C. M., Yin, E. C. K., Yee, K. S., \& Wei, L. K. Barriers of mobile commerce adoption intention: perceptions of generation $\mathrm{X}$ in Malaysia. Journal of Theoretical and Applied Electronic Commerce Research, vol. 12, no. 2, 37 53, 2017. https://doi.org/10.4067/S0718-18762017000200004.

[40] Naqvi, S. J., \& Al-Shihi, H. Factors Affecting M-commerce Adoption in Oman using Technology Acceptance Modeling Approach. TEM Journal, vol. 3, no. 4, pp. 315-322, 2014. 
[41] Ngai, E. W., \& Gunasekaran, A. A review for mobile commerce research and applications. Decision Support Systems, 43(1), pp. 3-15, 2007. https://doi.org/10.1016/j.dss.2005. $\underline{05.003 .}$.

[42] Nunnally, J. Psychometric Methods. New York: McGraw Hill, 1978.

[43] Pavlou, P. A., \& Fygenson, M. Understanding and predicting electronic commerce adoption: An extension of the theory of planned behavior. MIS Quarterly, pp. 115-143, 2006.

[44] Pousttchi, K., Tilson, D., Lyytinen, K., \& Hufenbach, Y. Introduction to the Special Issue on Mobile Commerce: Mobile Commerce Research Yesterday, Today, Tomorrow-What Remains to Be Done? International Journal of Electronic Commerce, vol. 19, no. 4, pp. 120, 2015. https://doi.org/10.1080/10864415.2015.1029351.

[45] Roy, S., \& Moorthi, Y. L. R. Technology readiness, perceived ubiquity and m-commerce adoption: the moderating role of privacy. Journal of Research in Interactive Marketing, pp. 1-52, 2017. https://doi.org/10.1108/JRIM-01-2016-0005.

[46] Sadi, A. H. M. S., \& Noordin, M. F, "Factors influencing the adoption of m-commerce: An exploratory analysis," in International Conference Industrial Engineering and Operations Management, January, 2011, Kuala Lumpur, Malaysia.

[47] Kumar, S., \& Kumar, V. Technology Integration for the Success of B2C M-Commerce in India: Opportunities and Challenges. IUP Journal of Information Technology, vol. 13, no. 1, pp. 24-35, 2017.

[48] Tarute, A., Nikou, S., \& Gatautis, R. Mobile application driven consumer engagement. Telematics and Informatics, vol. 34, no. 4, pp. 145-156, 2017. https://doi.org/10.1016/j.tele.2017.01.006.

[49] Wei, T. T., Marthandan, G., Chong, A. Y., Ooi, K. B., \& Arumugam, S. What drives Malaysian m-commerce adoption? An empirical analysis. Industrial Management \& Data Systems, vol. 109, no. 3, pp. 370-388, 2009. https://doi.org/10.1108/02635570910939399.

[50] Wu, J. H., \& Wang, S. C. What drives mobile commerce? An empirical evaluation of the revised technology acceptance model. Information \& Management, vol. 42, no. 5, pp. 719729, 2005. https://doi.org/10.1016/j.im.2004.07.001.

[51] Yadav, R., Sharma, S. K., \& Tarhini, A. A multi-analytical approach to understand and predict the mobile commerce adoption. Journal of Enterprise Information Management, vol. 29, no. 2, pp. 222-237, 2016. https://doi.org/10.1108/JEIM-04-2015-0034.

[52] Zhang, L., Zhao, J., \& Xu, K. Who creates trends in online social media: The crowd or opinion leaders? Journal of Computer-Mediated Communication, 21(1), pp. 1-16, 2016. https://doi.org/10.1111/jec4.12145.

[53] Zinnov. 'Smartphone market in India', 2015. [online] Available: http://vps.zinnov.com/ india-smartphone-market-in-india. [Accessed: June 12, 2017].

[54] Zhu, G., Sangwan, S., \& Lu, T. J. A new theoretical framework of technology acceptance and empirical investigation on self-efficacy-based value adoption model. Nankai Business Review International, vol. 1, no. 4, pp. 345-372, 2010. https://doi.org/10.1108/2040 $\underline{874101108 .}$.

\section{Authors}

Satwinderjit Singh is serving as a business analyst and project manager for an organization that specializes in the field of software, e-commerce and mobile application. A Bachelor of Computer Science graduate from Staffordshire University, UK, he has obtained Master of Communication (Integrated Marketing Communication) from Universiti Sains Malaysia, Penang. 
Dr. Izzal Asnira Zolkepli is a senior lecturer serving in the Persuasive Section of School of Communication, Universiti Sains Malaysia. Her area of specialization includes modelling consumer behavior, advertising and marketing futurecast via the convergence and adoption of digital, social and mobile media communication in the era of big data.

Cheah Wen Kit is a PhD candidate who is attached with the School of Communication, Universiti Sains Malaysia. He is also a lecturer of communication, specializing in digital and content marketing. His research interest is on consumer and online users' flow experience in the field of cyberpsychology via the optimization of gamification on value co-creation.

Article submitted 3 June 2018. Resubmitted and 17 August and 24 October 2018. Final acceptance 25 October 2018. Final version published as submitted by the authors. 